\title{
Street commerce as a 'problem' in the cities of Rio de Janeiro and São Paulo
}

Daniel Hirata

\section{Abstract}

The aim of this article is to describe how street commerce that has come to be seen as a 'problem' in two major Brazilian cities: Rio de Janeiro and São Paulo. The text concentrates on two periods - 1980 to 1990 and 2000 to 2010 - during which governmental intervention in street commerce radically changed, examining the flux of people and merchandise and the forms of this intervention.

Keywords: illegalism - street selling - government - entrepreneurshipmilitarization - securitization

\section{Resumo}

O objetivo do artigo é descrever como o mercado do comercio ambulante vem sendo construído como "problema" em duas cidades brasileiras: Rio de Janeiro e São Paulo. O texto centra-se em dois momentos de transformação das formas de incidência governamental e da conformação dos mercados do "comercio ambulante", entre os anos 1980/1990 e 2000/2010. Observa-se especialmente, as modalidades de circulações de pessoas, de mercadorias e de práticas governamentais.

Palavras-chave: ilegalismos - comércio ambulante - governo - empreendedorismo - militarização - securitização 


\section{Street commerce as a 'problem' in the cities of Rio de Janeiro and São Paulo}

Daniel Hirata (NECVU-UFRJ)

São Paulo and Rio de Janeiro differ widely in their social, cultural, economic, political and urban characteristics. However, in the specific case of the history of governmental intervention in the 'problem' of street commerce, these divergent aspects converge, as illustrated by a number of events that occurred in both cities, albeit at different times. It is not within the scope of this text to present a 'social history of street commerce'; it focuses, rather, on the transformations that occurred between 1980 and 1990 and 2000 and 2010 in the construction of the intelligibility of 'street commerce as a problem', in terms both of the legibility (DESROSIÈRES 2008) and of the instruments devised (LASCOUMES 2005) by government, as well as the power games in which the groups that dispute (and negotiate their participation in) this market engage'.

The type of regulations permitting the circulation and the consumption of goods sold on the street during the two above-mentioned periods stems from this dynamic relationship, the history of which will be outlined here. This is not a new approach; it is based on the seminal work of Karl Polanyi in which he demonstrates how the social construction of the markets is effected in its classical form (POLANYI, 1944), as in the genealogical trajectory of

\footnotetext{
1 Perceiving street commerce as a 'problem' or as a 'problem creating process' constitutes a research approach that closely resembles that way in which Michel Foucault, on several occasions, defined his own particular way of thinking and his historical work, as distinguished from the history of ideas, of representations and of mentalities. In this sense, the analysis of the conditions for the possibility of multiple solutions to a problem (facts, practices and thoughts) constitutes such a 'problem creating process'. Foucault's question is always: 'How was it possible?' See FOUCAULT, Michel. 2001. Dits et Écrits. Paris: Gallimard. Of special importance in this context: "Polémique, politique et problematisation" (text 342, volume IV).
} 
Michel Foucault's forms of contemporary governments (FOUCAULT, 2004), a concept that has made it possible to characterize the actuality of the situation. This text will examine how these radical changes have affected the role of force and the power games that characterize negotiations between the parties; it will delineate the shifting frontiers between practices that fall either within or outside the government's control; it will examine the way in which conflicts in the governance of these markets arise and reveal the emergence of the various transformations that are of interest to a historical examination of the subject. This text thus attempts to achieve a greater understanding of the 'popular' economy and the transformations to it that the new forms of institutional intervention in the day-to-day practices of street sellers have brought about.

\section{The 1980 s and 905 - The right to work in the street:evolution and regulation}

At the beginning of the 199os street commerce was characterized in both cities as a problem, as it indicated a failure in the organization of the relationship between the cities and their respective labor markets. Street sellers were not perceived as workers, but rather as a segment of the population that combined loiterers, the unemployed and those struggling to survive. For this reason the main form of interface between them and the government was constructed by means of policies and instruments for the maintenance of public order. The control of street commerce became an attribute of the municipal inspectors, with the support of the recently formed municipal guards $s^{2}$ that were summoned during the frequent confrontations that occurred between inspectors and sellers at a time when there were laws for the control and inspection of the activity, but none as yet that regulated it ${ }^{3}$. In both São Paulo and Rio de Janeiro these laws addressed the use of public spaces while failing to establish labor norms. Thus the central issue of dispute became the use of public spaces with severe penalties applied to

2 Although initially inspection was the attribute of the municipal inspectors, the use of force was applied jointly with the municipal guard. In São Paulo the Metropolitan Civil Guard was an institution that dated back to the beginning of the 2oth century; it was among the first in Brazil to be reinvented as a democratic institution in 1986 (law no 10115/86). In Rio de Janeiro the Municipal Guard was created by law no 1887/92 and instituted the following year.

3 In the case of Rio de Janeiro, law no 1876/92, and in São Paulo law no 11039/91. 
those that transgressed the law. Thus the juridical/political terrain was established in which the disputes were to occur: disputes over the control of the location of the sellers' stands. ${ }^{4}$

In a previous article I have broached the heuristic relevance of the street sellers' stands for a descriptive/analytical discussion of the various types of this 'informal' or 'illegal' commercial activity (HIRATA 2011). On that occasion I attempted to demonstrate that the use of force institutes 'mercantile exchanges' of which the street sellers' stands are the hub. The particular relevance of the stands in relation to street commerce as a whole is that they are the subject of specific forms of legal and extra-legal authorization for the purchase and sale of goods. The reference established by municipal regulations (the 'Stipulation of Permission for Use' in São Paulo - TPU in the Portuguese abbreviation - and the 'Stipulation of the Use of Public Areas' in Rio de Janeiro - TUAP) is the permission conceded for the use of public spaces for such sale. Contrary to other municipal authorization of commercial activity, the registration and concession of permission for the use of public spaces entirely fails to meet the sellers' expectations in at least three ways: the non-inclusive nature of the laws that restrict the granting of permission to sellers with a specific profile; the often unclear and contradictory criteria for concession-related decisions, a true example of the lack of legibility of government operations (DAS, POOLE 2004); and the complete lack of proportion between the number of authorized sellers and the number actually working on the streets, creating from the outset an inequality between demand and supply that will be hard to address. Although a number of court rulings have created jurisprudence favorable to the street sellers, the fact remains that the vast majority have not had their requests approved, or are simply selling merchandise on the streets without permission.

Due to the lack of clarity in the regulation of commerce in public spaces, the restrictions on the type of candidate that can register and the limited number of authorizations, the vast majority of stands effectively operate at

\footnotetext{
4 The term 'camelô', synonimous in Portuguese for street seller, is similarly ambiguous as both simultaneously designate the activity of purchase and sale, undertaken from a fixed point or in a mobile form in the streets of the city. For the purposes of this text this difference will be minimized, given that, even those sellers that are mobile generally exercise their activity within a defined perimeter, being influenced by the dynamic of the disputes over the location of stands.. On this difference between mobile and fixed camelôs see MAFRA, Patrícia (2005). A "pista" e o "camelódromo": camelôs no centro do Rio de Janeiro. Masters' dissertation, Museu Nacional Social Anthropology Program.
} 
the edges of the law. However illogical it may appear, they are nevertheless not excluded from 'business', nor abandoned by public institutions, as their operation is illegally authorized by officials (as, for example, the inspectors that take bribes during seizure operations). Thus my emphasis on the importance of this decisive interaction between government agents, sellers and suppliers. The sellers have a number of terms for referring to the bribes they pay to police: 0 acerto, a madeira, pagar pau. The term 'political merchandise' (MISSE 2006) has been adopted here to refer to these practices, that constitute the practical, daily interaction between those that control the 'informal' commercial sector and those that operate it. Although the street sellers used to pay bribes before, the regulation of the sector brought control practices that instituted the political goods market ${ }^{5}$. This was due, in the first place, to the fact that the regulation excluded the vast majority of sellers, forcing them to work illegally, and secondly because its instruments gave priority to the use of force against them, rather than promoting their economic integration. The use of force, legal or illegal, reinforced the process of the construction a market based on coercion.

Despite the problems that arise from the form of regulation, it nevertheless serves as a reference for the frontiers between legality and illegality and thus establishes guidelines for court rulings on the conflicts arising from the dispute over the legalization of stands. Before regulation the interaction between the agents in charge of inspection and the street sellers was weighted in favor of the former, who exercised their authority at random. This included the use of force, leaving the sellers completely at the mercy of case-by-case decisions as to who could and who could not sell merchandise or which sellers were to suffer penalties and which were not. This is why, despite their restrictive, limited and illegible nature, these laws (that were passed with no public consultation), are popularly referred to in both cities as the 'street sellers' law', as they establish a limited form of regulation, and protection (albeit precarious) for those involved in the activity. However,

5 'Political merchandise' and the 'political assets market' are concepts that occur in the writings of Michel Misse, in which his analysis distances itself from the concept of 'an economy of corruption' with its overemphasis on moral and institutional dysfunction. In his discussion of this specific market he considers not only the connection between supply and demand, but also the 'strategic assessments of power, the potential recourse to violence and the balance of forces, that is, evaluations that are strictly 'political'. See: MISSE, Michel. 2006. Crime e Violência no Brasil Contemporâneo. Rio de Janeiro, Editora Lumen Júris. Also PIRES, Lenin 2010. Arreglar não épedir arrego. Doctor's thesis, post graduation in anthropology at the Universidade Federal Fluminense. 
concurrently with the legal regulation of inspection, confrontations have become generalized, with the sellers adopting the slogan of their 'right to work in the street'. Where the municipality institutes the control of the activity the social conflict is structured by means of the ways the street sellers form associations.

This is a political dispute arising from the use of public space, the occupation of which these workers consider their right. With no official employment or any formal connection with an employee, the street sellers direct their demands at the municipal government as the body that authorizes the use of public spaces for the sale of merchandise. The form by which the activity was regulated, however, institutes the urban space as the center of the dispute, and the polarization between street sellers and the municipality as the two agents that negotiate in a conflictive manner the appropriation that can be made of the city

It was against the background of this legal/political scenario that the street sellers' associations and unions were formed. These organize activities that range from marches, demonstrations, public denunciations and court hearings, to the occupation of public spaces, including physical violence and attacks on municipal inspectors, all of which construct the repertory of the activity of the street sellers (TILLY 2008) ${ }^{6}$.

The history of these confrontations with the public authorities was constructed exactly at the point where government action supervenes, in other words, all the multiple scenario of disputes and negotiations of the groups that participate in this market in their alliances and conflicts with the institutions that produce the regulation of this juridical/political terrain. A series of these confrontations occurred in São Paulo between 1995 and 2002 directed against the so-called 'inspector mafia ${ }^{7}$ ', in a reaction to the kind of extortion that typifies 'political markets'. The result was a significant alteration

6 This argument confirms what Fernando Rabossi identified in Ciudad del Leste, where the legal/political framework led to the formation of associations. See: RABOSSI, Fernando. 2011. Negociações, associações e monopólio: a política de rua em Ciudad del Este (Paraguay). Etnográfica.15(1).

7 The 'bribery mafia' organized the system of payments made by street sellers to regional inspectors in return for 'authorization' to store merchandise, set up stalls and receive advance warning of police interventions. It also oversaw the collection of these funds by regional administrators from which pay-outs were made to town councilors who belonged to the political parties that supported the government. The funds, that provided personal wealth for the group as well as campaign finance, represented a traditional mechanism for the maintenance of the power structure in São Paulo. See: CARDOZO, José Eduardo. 200o. A Máfia das Propinas. São Paulo: Fundação Perseu Abramo. 
in the balance of power between the political parties in the city which led to an investigation into a group of town councilors and culminated in the impeachment of the then mayor Celso Pitta (CARDOZO 200o). Although the conflicts in Rio de Janeiro did not create as great an impact on the balance of power between the political parties, the resulting political tension was at times a decisive factor in shifts of power in the city. Less serious than in São Paulo, nevertheless the Map of Urban Conflicts in Rio de Janeiro ${ }^{8}$ shows that the largest number of confrontations in the city occurred between street sellers and municipal guards (NACIF 2011), a sign that the occupation of public spaces and the legal/political structure that governed them were also causes of conflict in Rio de Janeiro

There were two types of reaction on the part of the street sellers to this initial governmental intervention (mostly in the legal/political sphere). Although they frequently overlap, analytically they may appear as distinct forms of confronting governmental intervention: on the one hand, 'adaptation' practices within this 'political assets' market, and on the other practices of confrontation with the authorities affirming the right to work in the streets. These two distinct forms of achieving the right to continue their activity are organized by the same means. In this legal/political terrain some of the associations collect funds for paying illegal bribes to inspectors and municipal guards while others refuse to raise money for the illegal authorization of their activity, expressing their opposition through public denunciations, demands to local authorities and other agents that practice such abuses.

To summarize, I consider the most important element in the discussion so far to be the common ground between the governmental instruments of intervention and the groups that dispute and negotiate their participation in the street commerce market. The elements that characterize this are the following: firstly an approach to the control of these markets typified by the instruments of control selected and applied by government (even before the activity was officially regulated); secondly, the regulation of municipal authorization for the use of public spaces, characterized by the restrictions on

8 The Map of Urban Conflicts in the City of Rio de Janeiro is compiled as part of the Permanent Observation of Urban Conflicts program (ETTERN-IPPUR-UFRJ) that studies demonstrations in which 'the city is both location and target' based on the collection of data from the press and relevant government bodies. See: http://www.ettern. ippur.ufrj.br/projetos-em-andamento/38/observatorio-de-conflitos-urbanos-no-rio-de-janeiro 
registrations and the small number of concessions; and thirdly, the construction of a conflictive field (which I have called juridical/political terrain) that includes the political goods markets and the demands for the amplification of municipal concessions.

\section{The 2000 s and 20105 - militarization and entrepreneurship}

The dislocation that came about in the first two decades of this century has been highly significant in both Rio and São Paulo. While not supporting the hypothesis that 'everything has changed' I intend to examine some of these dislocations and their effect on the street sellers' problems. Some of the governmental instruments transform themselves, giving continuity to previous lines of action, while others remain the same but with contrasting significance in relation to their predecessors. What is different, in my opinion, is the far subtler approach to the management of the 'problems' concerning street commerce and significant alterations in the legal/political terrain. The edifice of the juridical/political territory does not collapse, but transforms itself from the departure point of a reading of the phenomena and of effecting the way in which the government organizes itself, a fact that evidently changes the surface of the contact of the relations between governors and governed.

At first these changes may appear to concern the relationship between the cities and their respective labor markets, with street sellers still being perceived as a mixture of loiterers, unemployed and those struggling for survival. But on further examination a different equation emerges, an equation that combines business activity with the imposition of public order. Street sellers have come to be seen as both offenders and have metamorphosed into entrepreneurs due to a combination of the intensification of public order policies, via the securitization and militarization of urban space, and the new regulations aimed at their urban and economic integration as entrepreneurs with access to credit facilities. The articulation between these two fronts of government action (both of which resulted from the continuous confrontations) reflects the alterations in government style, very similar in both cities. This new style has applied a selectivity to the 'problem' of street commerce; a process that either criminalizes the activity or transforms its status into that of an entrepreneurial activity, and thus alters the power struggle for the control of the wealth that flows through the streets of the two cities. 


\section{a) Partnerships, self-government and opportunities:}

Fundamental to an understanding of the change in the way in which street sellers are perceived as a 'problem' are the references adopted in the new rules that establish which of them are included and which excluded from operating legally. Unlike the 'legal/political' criteria for the concession of the use of public space that divided sellers into 'formal' (registered to pay tax) and 'informal' (unregistered) groups, the passing of supplementary law no 128/08 (an alteration to the General Law of Small Businesses - supplementary law no 123/06), that came into effect in $2009^{9}$, has altered the way in which street sellers' set about achieving authorization. The law established a number of advantages for what are termed 'individual small businessmen', offering an alternative to street sellers who wish to be incorporated into the formal economy under the terms of the new juridical entity with its entrepreneurial characteristics. The law included a number of benefits that are more 'inclusive' and transparent in relation to the registration process for the concession of public space: there are no profile restrictions, online registration is available to all candidates, official requirements are restricted to a once-yearly declaration of billing (that can also be made online) and candidates are exempt from business registration fees. Thus, when compared to the illegibility of the regulations for the concessions granted under the TPUs and the TUAPs the process is considerably easier and the cost virtually unchanged.

Among the law's most important aspects are the reduction in the tax rates charged to larger companies and the guarantee of far-reaching social welfare coverage that includes sick leave, pregnancy leave (after a given period) and a retirement pension (according to age). Thus the law confers the rights that are considered to constitute 'citizenship', or, in the words of Ministry of Trade 'the right to dignity, which in the human condition implies personal, professional and social realization. Being an officially registered businessman means holding one's head high, being able to say 'I am a citizen; I practice my profession according to the laws of my country. Being part of the formal economy means being a citizen ${ }^{\prime 0}$."

9 Supplementary law $123 / 06$, that establishes the rules that govern small companies, together with supplementary law 128/08, that creates the legal entity of the 'small individual businessman', are based on article 146 of the federal constitution that establishes the taxation norms that benefit small companies with lower tax rates and simplified tax regimes.

10 See the 'portal for entrepreneurs' on the website of the Ministry of Development, Industry and Foreign Trade: http://www.portaldoempreendedor.gov.br/ 
This new vision of citizenship, being part of the formal economy, is also supported by institutions such as SEBRAE (the Brazilian Agency for the Support of Small Businesses) and the state-owned banks that have programs for promoting 'self realization' among small businessmen. SEBRAE provides assistance during the registration process and follow-up support through technical courses, business planning and counseling in 'entrepreneurial training and aptitude.' State-owned banks such as the Banco do Brasil, the Banco do Nordeste and the Caixa Econômica Federal offer special credit facilities and credit lines at reduced rates. And lastly there is the 'opportunity' offered by the federal's government's authorization for the joint purchase of merchandise through consortia, with the advantage of lower prices for bulk purchase.

This new access to official registration has considerably altered government regulation of the activity. It is important to note, however, that the new model has not replaced the old, but rather has been superimposed upon it. This is because commercial activity in public spaces requires municipal as well as federal authorization. For those already installed in the streets there is no great advantage in becoming an officially registered small businessman as the most important benefits offered by the new law, notably health coverage, already existed under the simplified requirements of the TPUs the TUAPs. And only a few organizations took an interest in the sales and purchase consortia due to the cost of joint taxes. A slightly larger number took an interest in the credit facilities, not as individual small businessmen but as members of associations that, as registered small companies, achieved direct access to the banks. This trend, especially in Rio de Janeiro, facilitated access to credit through the intermediation of these associations, which also began to hire specialized companies for debt negotiation.

However, the major impact of the new legislation for the official registration of small businesses was to be found in closed environments, the so called camelódromos (street malls) that were set up in both cities in an attempt to assuage the conflict between the government and the sellers who considered it their 'right to work in the street ${ }^{\prime \prime 1}$. Curiously, it was precisely

\footnotetext{
11 This dynamic is very clear in the locations where the research was conducted. The Popular Market in Rua Uruguaiana, the first 'street mall' in Rio de Janeiro, was inaugurated in 1994 after an earlier attempt in 1984 to establish a 'street mall' in Praça XI had failed. It was the result of negotiations between the leaders of the street sellers and Governor Nilo Batista, in a continuation of the policies of former governor Leonel Brizola, who
} 
in these 'malls' that the new benefits were most widely adhered to, with the highest number of officially registered small businesses, the proliferation of entrepreneurial 'training' and 'aptitude' courses, the largest number of new consortia and the highest rates of access to credit. With their larger number of members and greater degree of organization, the associations (and later the committees that administered these closed environments) were far quicker to structure themselves within the framework of the new legislation and its benefits than their counterparts who worked in the streets.

What is noteworthy about the new diagram of entrepreneurship in the status of the street sellers from 'quasi workers' (belonging either to the 'formal' or the 'informal' economy) to that of 'quasi companies', with the consequent alteration in their interactions with government. The legal/ political framework had established a polarization between government and street seller that stemmed from the concession of municipal permission for the use of public spaces and was the cause of large-scale, ongoing conflicts and demonstrations throughout the period. The entrepreneurial system, on the other hand, has transformed the interaction between the two into a partnership through a convergence of interest in promoting the commercial sector.

As 'quasi workers' the street sellers had a 'quasi boss', the municipal government, with the hierarchical structure imposing a a virtual employeremployee relationship. Even if, in official terms, the street sellers were self-employed workers, the de facto relationship with the municipality, as I have attempted to demonstrate above, was one of subordination. The inequality of this relationship was reflected in the disputes over the occupation of public spaces (that characterized the above-mentioned polarization); it was not by chance that the street sellers in São Paulo referred to the state as their 'boss' and the associations they formed were mostly 'trade unions' that formed links to the Central Unica dos Trabalhadores (CUT) and the Força Sindical through political contacts ${ }^{12}$.

saw these spaces as offering potential for government action in favor of street sellers. In São Paulo the Feira da Madrugada was inaugurated in 2004, as a result of negotiations between the leaders of the street sellers and the then governor Marta Suplicy, in a continuation of policies initiated by former governor Luiza Erundina.

12 The CUT is a trade union that was founded in 1983, as part of the movement known as novo sindicalismo, in the wake of the widespread strikes of the previous years; it is currently the largest union in Brazil. The Força Sindical, the second largest in the country, was founded in 1991, positioned closer to the center of the political spectrum as a counterbalance to the left-wing ideological stance of the CUT. 
To the extent in which the governmental supervention metamorphosed the street sellers into 'quasi entrepreneurs' the polarization produced by an unequal and hierarchical relationship changed into a mutually agreed contractual agreement between two equal parties, or in other words, a partnership. As companies competing for the market of low-priced goods, the associations that administer the 'street malls' strive to respect the parameters established by the municipality, firstly by offering training courses that provide guidelines on how to work within the new legislation, and secondly by functioning as consortia for the purchase of goods and access to credit, often acting in conjunction.

Thus governmental intervention is no longer characterized by the limitations it imposed (mostly legal restrictions backed by police repression) but rather characterized by the mobilization of street sellers within the new entrepreneurial model. The previous parameters for the regulation of retail activity in public spaces were restrictive, limiting all such activity. With such practices the new entrepreneurial model stimulates such activity, providing incentives for street commerce and thus promoting the sector.

To summarize, the whole government approach to the issue has shifted from one of perceiving it as a problem to perceiving it as an opportunity for business. In both cities the activity, once considered a labor market problem and an indication of labor disorganization, is gradually being transformed into a front for greater economic development compared to that of other cities. An example of this can be seen in recent plans for urban renovation that now include spaces for street commerce. The current plans for 'shopping corridors' in São Paulo and for the renovation of the docklands of Rio de Janeiro in preparation for the major events that will occur there are examples of this shift in perception and of how government intervention has moved in the direction of entrepreneurialism. The competition between Brazil's major cities for economic resources has highlighted the importance of 'popular markets' as a significant component of urban economies; they are no longer seen as a problem of social exclusion and poverty but rather as an opportunity for the flow of wealth.

b) Military strategies and the securitization of urban space:

While the promotion of officially registered companies and the access to credit have been almost entirely limited to closed environments, 
intervention on the streets has been intensified and the number of arrests increased under the government's policy of securing public spaces. With the territorial occupation of certain areas and its ostensive use of coercive dissuasion practices, militarization has become the instrument of preference for the control of this commerce which is now the target of ongoing monitoring and security surveillance.

Certain points should be noted concerning the militarization and securitization of public spaces by government: firstly, the creation of new secretariats has produced a new 'institutional design' of municipal administration with the restructuring of the various coordination departments, subordinate divisions and other bodies related to public order; secondly, these new secretariats have established public order programs that utilize modern verification and monitoring techniques and have developed new instruments for the agents responsible for inspection, reorganizing their attributes and modifying their powers for exercising them. The work of these new secretariats has thus altered our approach to the question of these 'political markets' which are now characterized by this decisive interaction between the agents that control them and the street sellers who comprise their 'target group'. These secretariats, with their new approach and instruments, have opened up a new field for the examination of the effects of governmental action on these 'political markets'.

The Special Secretariat for Public Order (SEOP) was created on the first day in office of Rio's current mayor, Eduardo Paes (by decree law 30339 of January 1, 2009). This regulation revised the entire structure of the city's administrative powers for the maintenance of public order without consulting either its legislative body or the population. These exemptions, due to its 'special' (or priority) status, mean that the law is supposedly temporary, but in effect it is structured and operates in the same way as all the other municipal secretariats $^{13}$ (NACIF 2011). In São Paulo the Municipal Secretariat for Urban Safety (SMSU) was created by mayor Marta Suplicy in 2002. Although it was instituted by law no 12396/02 it also dispensed with any wider form of consultation. Its intention is stated as 'promoting the control of street commerce' for which its preferred operational instrument is the use of the Civil Guard.

13 Formerly independent bodies have been incorporated into the Secretariat. The District Council for Inspection now incorporates what was previously the Authorization and Inspection Unit and the Inspection Unit for Parking and Towing; the Council for Urban Control now incorporates what was previously the Operational Unit for Urban Control (the Municipal Guard.) 
This new institutional design, that emerged from the transformation of the old institutions into new secretariats, is characterized by the concept of coordinated management of public order. Coordination is required due to the increased effectiveness of public order management, which now has a wider scope, with the secretariats engaging the services of other municipal bodies through integrated management councils. Agreements have been entered into for cooperation with the district councils and other secretariats, including those for transport, public works and social assistance, that traditionally have no connection with the maintenance of public order. The municipal government has redefined the rules for the use and occupation of urban space by making use of the existing regulations at its disposal, such as the Construction Code (that defines building norms) and the Code of Conduct (that defines the social practices permitted in public places) resulting in a highly effective and consistent normalization of the use of urban space.

Thus from point of view of 'best practices' the coordinated management approach is amply justified as a demonstration of 'technical and administrative common sense'. The same cannot be said, however, of the perception that the control of public spaces in the city is a matter of protecting public order. This militarized security approach has made public safety the priority at the expense of harmonious coexistence, with increased regulation of what is permitted and increased policing of behavior in public spaces (TELLES 2012), including the incrimination of urban types seen as undesirable for social contact and forcibly expelled from areas under military control. This is a new form of urbanism whose main concern is public safety (OBLET 2008). On the one hand it is anchored in the 'new military urbanism' (GRAHAM 2011) that aims at the integration of police strategy with urban planning, and on the other in what is termed 'governmental acclimatization' (BOULLIER 2007), an important contemporary model for the urban organization that has abandoned the idea of 'deep causes' in favor of dealing with 'surface events'. Thus methods of surveillance and militarization become integrated with the creation of urban spaces, altering the very concept of what constitutes these spaces of coexistence, that are no longer perceived as places of citizen appropriation (LEFEBVRE 1968) but rather as a means for the construction of urban order.

For an exposition of the significance and effects of this new form of construction of public order it is fundamental to understand precisely how 
the programs of these secretariats operate. Despite the general success of the SMSU, the experience of transferring the attributes of the inspectors to the municipal guard has not been seen as entirely successful. São Paulo's municipal guard is one of the most militarized in the country; nevertheless its control of street commerce has been seen as not being sufficiently 'energetic' in terms of 'imposing itself'. The effective acquisition of coercive control was legally granted a few months after the transference of control, on December 2, 2010, in an agreement signed between the state (representing the military police) and municipal (representing the district councils) governments of São Paulo (law no 14977/og and decree no 50994/o9, commonly known as 'operation delegation'). The new law allowed military policemen (a state controlled body) to work for the municipal government for up to 96 hours per month on their days off, in return for extra pay.

The operation began with an intervention in the area of Rua 25 de Março, and a few days later the head of the military police announced a reduction in the occurrence of minor crimes such as theft. The results were divulged in indices that indicated a reduction in petty crime and were hailed as proof of the unquestionable success of the intervention, which was then extended to other areas of the city. Street commerce was included in these indices of reduced criminal activity, even though the activity in itself does not constitute a crime. It would appear as no coincidence that at the same time the municipal government also assumed the responsibility for the repression of pirated goods (by means of a global program organized jointly by the UN and the World Bank that had recently been adopted by the Ministry of Justice) ${ }^{14}$.

However, the significance of this delegation of functions, that effectively means the transfer of responsibility for the control of street commerce from the inspectors appointed by the district councils, with backup from the municipal guard, to the military police, goes deeper than might appear at first sight. More than merely a means of providing extra remuneration for police with the justification of a reduction in criminality, it constitutes a 'legal shortcut' that violates the constitutional division between the roles

14 The Justice Ministry's program is called 'City Free of Pirated Goods' and is administered by the Brazilian Institute for Ethical Competition. The program attacks piracy on a number of fronts, including promoting municipal responsibility for the fight against pirated goods, with incentives to town councils for the 'creation of local mechanisms for their prevention and suppression' and the 'prevention of this illegal commerce' by local government. 
of the two institutions, diluting the specific attributes of the inspectors in favor of expanding the powers of the military police. It was the provisions of this new law that enabled the military police to intervene in the traditional district of Brás, the center of 'popular' commerce in São Paulo, during which storm troopers, cavalry, mobile bases and special units were employed in large numbers for the occupation of the district.

However, this centralization of attributes, previously divided, has led to a greater degree of agility and efficiency in the day-to-day control of the district of Brás. Major Wagner Rodrigues, head of the administrative and operational division for the city center, has stated that this conception of inspection stemmed from a number of experiences of previous operations that he had commanded, and that it was now realized that the division of attributions 'prevented efficient control'. As an example he cited the 'parachutes' - street seller that spread out their merchandise on cloths to enable them to make a quick escape when the inspectors appear - as when the cloth was spread out on the ground inspection was an attribute of the municipal guard, whereas when it was rolled up in the form of a bag only the military police were empowered to conduct a search. This "small interactive scene of social control" illustrates what has changed in the daily routine of the district: in the first place the discretionary powers of a policeman working on his days off are now broader than those he is attributed when working officially, as 'operation delegation' has limited the attributes of the municipal guard and the district councils' inspectors; in addition, these broader powers are guaranteed by their superiors, policemen appointed to positions of command by the district councils, responsible for the overall planning and operation of inspection, including seizure of goods and the occasional arrest of street sellers in a process that could be termed administrative 'insulation ${ }^{15}$.

In Rio de Janeiro, the main activity of the SEOP has been a series of operations known as 'Choques de Ordem' (public order offensives). At the outset these operations caused considerable impact by which the municipal government was 'sending the message': its new model of intervention, characterized by its multiplicity, mobility and media impact (VELLOSO 2012), meant that

15 Military police officers have been appointed to managerial posts in the District Councils that come under the control of the State Secretariat for Public Safety, the Transport Secretariat and the Traffic Control Division (CET), as well as in the Funeral Service, the Ambulance Service and the Civil Defense Department. See the report by Gabriela Moncau in Revista Caros Amigos, July 2011 edition, 'Kassab reforça o Estado Policial em São Paulo'. 
'everything had changed'. In its first year it conducted a new registration process for all street sellers (the Consolidated Street Commerce Register CUCA). In its second year the SEOP renewed its public order offensives, now called 'Choque de Ordem II' for which the most important operational instrument was the Public Order Units (UOPs). This was a time when major police operations to occupy and pacify the favelas in Rio de Janeiro (UPPs) were having enormous impact and repercussion; the UOPs' model of territorial occupation reinforced the practice (that had already been established during the first 'Choque de Ordem'). Thus the permanent occupation of territory by the forces of public order has come to be seen as the most effective form of applying the programs and projects of the SEOP.

The first indication of the new strategy came with the arrival of the municipal guard in the early hours of the morning, before the sellers had set up their stands. The commander of the municipal guard has stated that 'territorial domination' before the stands open for sale facilitates intervention; it serves as a warning, showing who's 'in command', and incurs lower 'costs' than interventions that occur later in the day. Thus the effectiveness of territorial control, previously applied by the municipal guard, has been reasserted in the wake of the installation of the UPPs (the pacification of the favelas). However, as territorial occupation was not an attribute of the municipal guard, the question arose of which new instruments should be adopted. Nevertheless, even with the increase in the trend towards territorial occupation, the central role of the municipal guard in SEOP's operations has continued to increase, consolidating its position as the leading instrument for the control of social and urban space issues. In fact it is the employment of the municipal guard that has made the implementation of the UOPs and territorial occupation possible as political strategies for maintaining public order.

The increase in the powers of the Municipal Guard was intended to achieve the strategic aim of increasing its efficiency as an instrument of intervention in the control of public space, the new model of which is now territorial occupation. This has led to far-reaching changes that include new operating, planning and result assessment methodology, including the mapping out of areas with specific characteristics and an evaluation system based on questionnaires answered by local inhabitants; the purchase of modern devices such as smart phones and tablets connected to an operations intelligence center; far-reaching structural changes contained in the Standard Operational 
Procedure (POP); training programs for the use of new technology and the reformulation of the Special Operations Group (GOE), that had existed previously, but whose role is now to 'prepare the terrain' for the installation of the UOP (in the same way as the military police's Special Operations Battalion does prior to its interventions during the pacification of the favelas), thus becoming the predominant agent for the occupation of public space, with a wide range of coercive and dissuasive instruments at its disposal.

\section{Conclusion}

The occupation of the central districts of both Rio de Janeiro and São Paulo has altered the dynamic of decisive interaction between the street sellers and the agents responsible for the control of their activity. In both cities the adoption of territorial occupation as a form of control has resulted in a 'centralization' of the 'assets' of this 'political market'. In direct terms this means extortion has become 'wholesale', as it is now negotiated between the military command and the associations that run the 'street malls' and control the flow of merchandise. The associations of sellers who work in the streets are less well organized, without the capacity to pay the increased price of these 'political assets'; they are thus excluded from the negotiations, except for occasional handouts (or 'retail' extortion) where there is no guarantee that in return their activity will be protected.

Thus the selective application of policies that encourage the creation of companies and provide access to credit, alongside those that promote the increased policing and securing of public spaces, have entirely altered the nature of the disputes involving the location of stands. The inevitable process of the incorporation of the activity into the formal economy is being assisted by the authorization of closed environments ('street malls') that reinforce the tendency towards economic concentration and political centralization, as well as by the emphasis on the policing and securing of public spaces. It would be an exaggeration, and therefore incorrect, to say that these changes have been purposefully enacted in order for the markets to operate in this way; but a combination of tendencies unquestionably exists within the government that produce effects of this kind.

In summary, it is the unpredictable conditions of the time that determine the dynamic that composes the power groups that dispute and negotiate 
the flow of merchandise and the enormous potential for profit generated by street commerce in cities like Rio de Janeiro and São Paulo. These conditions depend upon the exercise of their legal authority by state institutions, that are both their product and producer. Whenever a new regulation, law or decree is sanctioned by municipal, state or federal authorities, the conflicts between these power groups assume a different form. At the same time these groups exert what pressure they can to influence the law making process. In the case of the groups that dispute the 'popular' commerce these conflicts register a structural selectivity that possesses a spacialized form. This, then, is the threefold process that now governs the locations of street stands: where they are permitted and even encouraged, where they are merely tolerated and where they are repressed with the utmost severity.

The issue indicated here is a change in the differential management of illegalisms (FOUCAULT 1976); in other words, the alteration in the balance between tolerance and repression as selectively applied to these markets. According to Foucault, in order to acquire an understanding of how this selection process works one must examine the power games that delineate the frontiers (between legality and illegality) (TELLES, HIRATA 2010). In the case of street commerce this reference of the demarcation of the frontier between legal and illegal has been disclocated from the old juridical terrain by means of the new policies that promote the registration of companies and access to credit (that have included some of the street sellers), while at the same time the militarization and securitization of urban space have become more radical, incriminating the vast majority that has been excluded from these policies. This does not mean to say that the dispute for street commerce has ceased, but that it now occurs under entirely different conditions with a segment of the sellers permitted to work with the blessing of the very government that represses the activity of their comrades in public spaces.

In this brief discussion of the way in which street commerce has come to be seen as a 'problem' in the cities of Rio de Janeiro and São Paulo, I have attempted to outline the changes in the type of governmental intervention in this activity. It is this delineation of the frontiers between legality and illegality, and the effective positioning of day-to-day practices within this spectrum, whether or not in accordance with state control of the activity, that characterizes the control of the immense volume of wealth that circulates through the commerce conducted on the streets of Rio de Janeiro and 
São Paulo. It remains to be seen whether the conflicts over the authorization of street stands will assume new characteristics due to this government approach of 'street commerce as a problem', or whether the fundaments of the dispute will be called into question.

Translated from the Portuguese by Mark Carlyon

Received October $14^{\text {th }} 2013$, approved October $27^{\text {th }} 2013$

\section{Bibliography}

BOULLIER, Dominique et alii. 2012. Evénements et Sécurité: les professionnels des climat urbain. Paris: presses de l'école de mines.

CANELLAS, Lidia. 2010. Camelô no Camelódromo não fica na pista. Uma etnografia acerca da construção e desconstrução de regras no Mercado Popular da Uruguaiana -RJ. Master's dissertation, UFF - Rio de Janeiro.

CARDOZO, José Eduardo. 200o. A Máfia das Propinas. São Paulo: Fundação Perseu Abramo.

DAS, Veena ; POOLE, Deborah. 2004. Antropology in the margins of the State. Oxford, Santa Fe: James Currey, School of American Research Press. DESROSIÈRES, Alain. 2003. " Historiciser l’action publique : L'État, le marché et les statstiques ». In: LABORIER, Pascal; TROM, Danny. 2003 (orgs). Historicités de l'action publique. Paris : PUF. pp.207-221.

DESROSIÈRES, Alain. 2008. Gouverner par les nombres. Paris: Presses de l'école de mines.

FREIRE, Carlos.2008. Trabalho informal e redes de subcontratação: dinâmicas urbanas da indústria de confecção em São Paulo. Master's dissertation, Universidade de São Paulo - São Paulo.

FOUCAULT, Michel. 2001. Dits et Écrits. Paris: Gallimard.

FOUCAULT, Michel. 2008. Segurança, Território, População. São Paulo: Martins Fontes.

GRAHAM, Sthephan. 2011. Cities under siege: the new military urbanism. Londres: Verso.

GUPTA, AKhil; SHARMA, Aradhana.2006. The Anthropology of the State. Oxford: Blackwell Publishing.

HACKING, Ian. 2006. Making up people. London Review of Books, 28(16). pp.161171. 
HIBOU, Beatrice. 1998. « Retrait ou rédeploiment de l'État ». Critique Internationale. 1. pp. 151-168.

HIBOU, Beatrice. 2013. La bureaucratisation néolibéral. Paris: La découverte. HIRATA, Daniel Veloso.2010. Sobreviver na adversidade: entre o mercado e a vida.

Doctor's thesis, Universidade de São Paulo - São Paulo.

LASCOUMES, Pierre ; LE GALÉS, Patrick. 2004. Gouverner par les instruments.

Paris. Paris: Presses de la fondation nationale de sciences politique.

LEFEBVRE, Henry. 2001. O direito à cidade. São Paulo: Centauro.

MACHADO DA SILVA, Luis Antônio. 2002. Da Informalidade a Empregabilidade (reorganizando a dominação no mundo do trabalho). Cadernos $\mathrm{CRH}, 37$.

MAFRA, Patrícia 2005. A “pista” e o "camelódromo": camelôs no centro do Rio de Janeiro. Master's dissertation, Post-graduation program in Social Anthropology at the Museu Nacional - Rio de Janeiro.

MISSE, Michel. 2006. Crime e Violência no Brasil Contemporâneo. Rio de Janeiro: Editora Lumen Júris.

NACIF, Cristina Lontra. 2011. Estado de Choque: Legislação e conflito no espaço público da cidade do Rio de Janeiro-Brasil (1993-2010). Paper presented at the XIV National Reunion of ANPUR.

PIRES, Lenin 2010. Arreglar não é pedir arrego. Doctor's thesis, Post-graduation program in Anthropology at the Universidade Federal Fluminense - Rio de Janeiro.

POLANYI, Karl. 200o. A grande transformação. Rio de janeiro: Elsevier.

OBLET, Thierry.2008. Défendre la ville: la police, l'urbanisme et les habitants. Paris: PUF.

RABOSSI, Fernando. 2011. Negociações, associações e monopólio: a política de rua em Ciudad del Este (Paraguay). Etnográfica. 15(1).

ROSE, Nicolas \& MILLER, Peter. 2008. Governing the present. Cambridge: Polity Press.

SENELLART, Michel. 2006. As artes de governar. São Paulo: Ed.34.

TELLES, Vera; HIRATA, Daniel. 2007. Cidade e práticas urbanas: nas fronteiras incertas entre o ilegal, informal e o ilícito. Revista Estudos Avançados 21(61).

TELLES, Vera; HIRATA, Daniel. 2010. Ilegalismos e jogos de poder em São Paulo. Tempo Social, 22(2).

TILLY, Charles. 1996. Coerção, Capital e Estados Europeus. São Paulo: Edusp. TILLY, Charles. 2008. Politique(s) du conflit: de la grève à la revolution. Paris: presses de science po. 
VELLOSO, Natalia. 2012. Políticas da ordem: poder e imaginação na criação da cidade olímpica. Master's dissertation, IPPUR - Rio de Janeiro.

\section{Other sources}

"Trabalho informal e direto a cidade" project report produced at the Centro Gaspar Garcia de Direitos Humanos, 2011

Caros amigos magazine, July 2011. "Kassab reforça o Estado Policial em São Paulo". Report by Gabriela Moncau. 